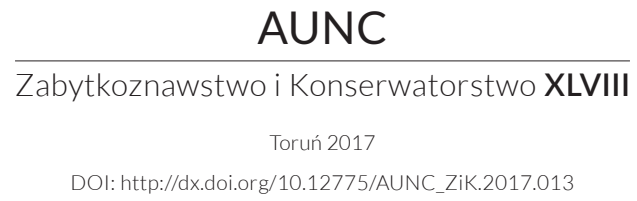

\title{
Polichromie ścienne Jerzego Nowosielskiego w cerkwi w Górowie Iławeckim - zagadnienia technologii i techniki malarskiej
}

\author{
MAGDALENA KAPKA \\ Zakład Konserwacji Malarstwa i Rzeźby Polichromowanej, \\ Wydział Sztuk Pięknych, UMK w Toruniu \\ e-mail:kapka@umk.pl
}

Keywords: wall painting, Jerzy Nowosielski, Greek-Catholic church in Górowo Iławeckie, technology, techniques, UV, XRF, SEM-EDX, „false colour” technique

Słowa kluczowe: malarstwo ścienne, Jerzy Nowosielski, cerkiew w Górowie Iławeckim, technologia, technika, UV, XRF, SEM-EDX, technika fałszywych kolorów

\begin{abstract}
Jerzy Nowosielski wall paintings in the Greek-Catholic church in Górowo Iławeckie - issues of artists' technology and techniques

The artistic output of Jerzy Nowosielski includes works of various subject matter and technique. An important part of his works is monumental painting in the temples of the Roman and Greek Catholic and Orthodox denominations. Among these are wall paintings in built in the Gothic style Greek Catholic Church in Górowo Iławeckie, that the painter made in 1984-1985. The article presents selected issues of technology and techniques of polychrome, whose interpretation was based on the results of the following: observation of the paintings in visible and UV light, analysis of the photographs taken in near infrared, UV-fluorescence, energy-dispersive X-ray spectroscopy (XRF), Scanning Electron Microscopy with Energy Dispersive X-ray Spectroscopy (SEM-EDS), Fourier Transform Infrared Spectroscopy (FTIR), microscopic analysis of cross-sections of paint layer samples (standard VIS- and UV- fluorescence microscopy). Identification of pigments was carried out also using the interpretation of photographs taken in the technique "false color" and microchemical analysis of
\end{abstract}


acquired samples of paint layers. These studies helped to define specific features of Jerzy Nowosielski painting, related to the choice of painting materials and methods of their use, especially those that determine the uniqueness of his style and makes his works instantly recognizable.

\begin{abstract}
Abstrakt
Twórczość Jerzego Nowosielskiego obejmuje dzieła o zróżnicowanej tematyce oraz technice wykonania. Ważną część tej twórczości stanowi jego malarstwo monumentalne w świątyniach rzymsko i greckokatolickich oraz prawosławnych. Wśród tych realizacji znajdują się malowidła ścienne w wybudowanej w gotyckim stylu cerkwi greckokatolickiej pw. Podwyższenia Krzyża Świętego w Górowie Iławeckim, które malarz wykonał w latach 1984-1985. Artykuł prezentuje wybrane zagadnienia technologii i techniki tych polichromii, których interpretację przeprowadzono na podstawie wyników następujących badań: obserwacji malowideł w świetle VIS oraz promieniowaniu UV, analizy fotografii w bliskiej podczerwieni, fluorescencji UV, rentgenowskiej analizy fluorescencyjnej (XRF), energodyspersyjnej mikroanalizy rentgenowskiej z zastosowaniem mikrosondy elektronowej (SEM-EDS), spektroskopii w podczerwieni z transformatą Fouriera (FTIR), analizy przekrojów poprzecznych przy użyciu mikroskopii standardowej VIS i mikroskopii fluorescencyjnej UV. Identyfikację pigmentów przeprowadzono również na podstawie interpretacji fotografii wykonanych w technice „fałszywych kolorów” oraz analizy mikrochemicznej pobranych próbek. Badania te pozwoliły sprecyzować charakterystyczne cechy malarstwa Jerzego Nowosielskiego związane z wyborem materiałów malarskich i sposobami ich użycia, szczególnie takimi, które decydują o niepowtarzalności jego stylu i czynią jego dzieła natychmiast rozpoznawalnymi.
\end{abstract}

Jerzy Nowosielski to jeden z najważniejszych artystów drugiej połowy XX wieku. Jego malarstwo łączy w sobie cechy zarówno sztuki dawnej, jak i nowoczesnej - w szczególności bizantyńsko-ruskiej, antycznej i wczesnochrześcijańskiej oraz sztuki abstrakcyjnej, kubizmu, surrealizmu. W twórczym dorobku Nowosielskiego ważne miejsce zajmują monumentalne realizacje, będące pewną kwintesencją jego artystycznych możliwości. Znajdują się one w wielu świątyniach w Polsce: grecko- i rzymskokatolickich oraz prawosławnych, a także w cerkwi greckokatolickiej pw. Zaśnięcia NMP w Lourdes we Francji ${ }^{1}$. Podobnie jak cała twórczość krakowskiego malarza, są odzwierciedleniem jego wschodniej duchowości, malarskim odbiciem bogatego świa-

1 Wykaz monumentalnych dzieł artysty zob. Krystyna Czerni, „Katalog projektów i realizacji sakralnych Jerzego Nowosielskiego”, w Krystyna Czerni, Nowosielski (Kraków: Znak, 2006), 209-215. 
topoglądu, prostolinijności, a także życiowej mądrości zwykłego człowieka. Liczne wypowiedzi Nowosielskiego na tematy z pogranicza teorii sztuki, religii i filozofii, którym poświęcono wiele rozważań w publikacjach dotyczących jego życia i twórczości, dopełniają przesłanie malarskiej działalności artysty dość wyczerpująco. Natomiast wciąż mniej znana jest warsztatowa strona jego malarstwa. Monumentalne polichromie Jerzego Nowosielskiego, wymagające od artysty szczególnej świadomości w kwestii wyboru i sposobu użycia materiałów malarskich, zainspirowały autorkę artykułu do przeprowadzenia analizy technologiczno-technicznej na przykładzie polichromii ściennych w cerkwi w Górowie Iławeckim.

Greckokatolicka cerkiew pw. Podwyższenia Krzyża Świętego w Górowie Iławeckim (fot. 1) wykorzystuje architekturę dawnego kościoła, wybudowanego około 1367 roku w stylu gotyckim. Po sekularyzacji Prus katolicka świątynia została przekształcona na ewangelicką. Jej wnętrze na przestrzeni lat podlegało licznym zmianom. Po pożarze w połowie XVII wieku wyremontowano strop i kościół na nowo wyposażono, dodając monumentalne malowidło. Duże spustoszenia powodowały w nim wszelkie działania wojenne. W XX wieku stale zmniejszająca się liczba ewangelików sprawiła, że kościół powoli przestawał pełnić funkcje sakralne. W roku 1947, w wyniku akcji Wisła, do Górowa zostali przesiedleni Ukraińcy. Nie mając własnej świątyni - spotykali się na nabożeństwach w prywatnych domach - wielokrotnie zwracali się do Urzędu do spraw Wyznań w Warszawie o zgodę na przejęcie opuszczonego kościoła na potrzeby swego kultu, jednak ich prośby nie zostały uwzględnione. W latach siedemdziesiątych w budynku świątyni urządzono magazyn wikliniarski. Na początku lat osiemdziesiątych Wojewódzki Konserwator Zabytków w Olsztynie pozytywnie rozpatrzył prośbę ówczesnego proboszcza parafii greckokatolickiej Juliana Gbura o przeprowadzenie remontu konserwatorsko-adaptacyjnego dawnego kościoła ${ }^{2}$. Główny projekt adaptacji budowli opracował inż. Bohdan Boberski ${ }^{3}$, natomiast do wykonania malowideł ściennych oraz ikonostasu został zaproszony Jerzy Nowosielski.

2 Paula Ciężka, „Artystyczna asymilacja. Przemiany historyczno-kulturowe w obecnej cerkwi w Górowie Iławeckim”, w Światło Wschodu w przestrzeni gotyku, red. Katarzyna Pasławska-Iwanczewska (Górowo Iławeckie: Parafia Greckokatolicka pw. Podwyższenia Krzyża Świętego, 2013), 245-258.

3 Ciężka, Artystyczna asymilacja, 258. 
Artysta wykonał zlecenie w latach 1982-1984, we współpracy z Haliną Onichimiuk-Piękny ${ }^{4}$.

Jerzy Nowosielski wcześniej nie był w górowskiej cerkwi, choć zazwyczaj dokładnie przygotowywał się przed wykonaniem tak monumentalnych prac, tworzył makiety, wstępne rysunki, projekty. Ikonostas powstał w pracowni artysty i kwestię jego dopasowania i montażu trzeba było rozwiązać już na miejscu. Natomiast wizja kompozycji i kolorystyki polichromii ściennych oraz koncepcja ich usytuowania zrodziła się właściwie tuż przed ich wykonaniem. Poważnym estetycznym wyzwaniem było dla artysty wpisanie swojego oryginalnego malarstwa w zastaną sytuację: we wnętrzu kościoła bowiem, decyzją architekta, został odsłonięty i oczyszczony ze starych tynków ceglany wątek ścian, a na drewnianym stropie pozostały barokowe polichromie (jeszcze przed konserwacją). Program ikonograficzny malowideł dopasowany został zatem do przestronnej, ascetycznej bryły jednonawowego kościoła i kolorystyki wnętrza, ale także do potrzeb liturgii katolickiej obrządku wschodniego. Z pewnością nawiązuje do sztuki bizantyńsko-ruskiej, a jednocześnie odzwierciedla daleki od konwencjonalnego stosunek Nowosielskiego do tradycji ikonograficznej ${ }^{5}$.

Najważniejszym elementem wystroju kościoła jest wykonany przez Jerzego Nowosielskiego ikonostas w postaci niskiej przegrody ołtarzowej, zwieńczony krucyfiksem. Malowidła ścienne pędzla artysty zostały usytuowane w nawie pod oknami, na parapecie chóru muzycznego oraz na ścianie zachodniej, w prezbiterium za ikonostasem na ścianach wschodniej i południowej oraz (jedno) w przedsionku cerkwi. Na ścianie południowej pod pierwszym oknem od strony ikonostasu widnieją święci Włodzimierz, Olga i Antoni Pieczerski, pod drugim oknem - święci Jerzy, Maria Magdalena, Joanna, Maria Egipcjanka, Kosma i Damian, pod trzecim - święci Dymitr, Jan Damasceński, Grzegorz Palamas, Szymon Nowy Teolog, Jozafat i Julian (fot. 2, 3). Na parapecie chóru muzycznego ukazano scenę Deesis: Chrystus, Matka Boża oraz św. Jan Chrzciciel, którym po bokach towarzyszą Archanioł Gabriel i Archanioł Michał. W prezbiterium za ikonostasem na ścianie południowej znajdują się przedstawienia Mandylionu i św. Piotra, a na ścianie

4 Krystyna Czerni, „Projekty i realizacje sakralne Jerzego Nowosielskiego dla cerkwi greckokatolickiej”, w Światło Wschodu, 81-82.

5 O programie ikonograficznym malowideł J. Nowosielskiego w cerkwi w Górowie Iławeckim zob. Joanna Piotrowska, „Jerzy Nowosielski wobec tradycji bizantyńskiej”, w Światło Wschodu, 121-130. 
południowej świętych Jana Chrzciciela, Klementa, Efrema Syryjskiego i Grzegorza Cudotwórcy. Na ścianie północnej pod pierwszym oknem od strony ikonostasu ukazani są święci Borys, Gleb i Teodozjusz Pieczerski, a pod drugim oknem - święte Katarzyna, Barbara i Paraskewia. Ścianę zachodnią zdobi namalowany bezpośrednio na cegle wizerunek Matki Bożej w typie Orantki (fot. 4). W przedsionku płytką niszę wypełnia malowidło przedstawiające Matkę Bożą z Dzieciątkiem.

Spośród wszystkich dekoracji malarskich autorstwa Jerzego Nowosielskiego jako pierwszy znalazł się we wnętrzu świątyni ikonostas i z pewnością miał decydujący wpływ na kompozycję i kolorystykę polichromii w nawie i prezbiterium, które z założenia miały stanowić jego dopełnienie. Przedstawione na ikonostasie postaci, namalowane przy użyciu typowych dla Nowosielskiego kolorów, przykuwają uwagę przede wszystkim intensywnymi czerwieniami, błękitami, oranżami i żółcieniami oraz głębokimi brązami w karnacjach. Kolory te silnie kontrastują z białymi tłami, które dodatkowo intensyfikują soczystość barw. Takie same rozwiązania kolorystyczne Nowosielski zastosował w polichromiach podokiennych nawy oraz na parapecie chóru - ich białe tła mocno kontrastują z intensywną kolorystyką ukazanych na nich świętych. Malowidła te są do siebie podobne nie tylko pod względem kolorystycznym, ale również kompozycyjnym. Wszystkie mają zbliżone rozmiary i są obramowane błękitnym paskiem. Te same błękitne pasy wyznaczają podział obrazów na dwa lub trzy pola, w których święci ukazani są w popiersiu lub w całej postaci. Niektóre pola w dolnej partii mają ciemne tło imitujące podłoże. Inaczej wyglądają polichromie w prezbiterium i na ścianie zachodniej nawy. Pokaźnych rozmiarów przedstawienie Matki Bożej Orantki nie zostało ograniczone żadnymi ramami kompozycyjnymi, podobnie jak Mandylion w prezbiterium. Jedynie popiersie św. Piotra zostało wpisane w błękitne obramienie, przypominające kolistą mandorlę. Malowidła na przeciwległych ścianach - południowej i północnej -korespondują ze sobą kolorystyką: można na nich odnaleźć takie same dominujące intensywne czerwienie, błękity i brązy.

We wszystkich przedstawieniach widoczne są typowe cechy twórczości Jerzego Nowosielskiego, które zapewniają mu natychmiastową rozpoznawalność. Należą do nich: frontalne ujęcie postaci świętych, podłużne, charakterystycznie wydłużone sylwetki, dwuwymiarowość przestrzeni, operowanie płaskimi plamami barwnymi, brak światłocienia, uproszczony modelunek, linearyzm, geometryzacja form, posągowość i dostojeństwo oraz - co naj- 
bardziej charakterystyczne - ikonowa, ciemna karnacja. Należy podkreślić, że Nowosielski znał doskonale wschodnią ikonografię i zasady pisania ikon - nauczył się ich podczas pobytu w studyckiej Ławrze Jana Chrzciciela pod Lwowem, której tradycje nawiązywały do słynnego klasztoru Studios założonego w Konstantynopolu w V wieku ${ }^{6}$ - lecz celowo wykraczał poza sztywne ramy ikonopisania, co często wzbudzało liczne kontrowersje, a nawet spotykało się z brakiem akceptacji wśród konserwatywnych odbiorców. Niejednokrotnie też powtarzał, że zachowując wierność podstawowym zasadom tradycji trzeba się zdobyć na twórczą odwagę, inaczej nie można przekroczyć granicy zbożnej archeologii ${ }^{7}$ Ta swoboda w posługiwaniu się konwencją ikony miała źródła, zdaniem Krystyny Czerni, w zakorzenieniu artysty w polsko-ukraińskiej tradycji - dla Nowosielskiego był to język wciąż żywy, a nie sztucznie wykoncypowany środek wyrazu. Takie „spoufalenie” dało mu dużo wolności, pozwalając na odchodzenie od tradycyjnych, technologicznych receptur $^{8}$, co potwierdzają również przeprowadzone badania.

Przedmiotem szczegółowych badań były malowidła ścienne Jerzego Nowosielskiego znajdujące się w nawie pod oknami, na ścianie wschodniej w prezbiterium oraz na ścianie zachodniej. Interpretację technologiczno-techniczną oparto na wynikach badań nieinwazyjnych, czyli analizy wizualnej w świetle widzialnym i ultrafiolecie, fotografii w bliskiej podczerwieni, techniki „fałszywych kolorów”, fluorescencji powierzchni malowideł w promieniowaniu $\mathrm{UV}^{9}$, a także badań inwazyjnych obejmujących: rentgenowską analizę fluorescencyjną (XRF) ${ }^{10}$, energodyspersyjną mikroanalizę rentgenowską z zastosowaniem mikrosondy elektronowej (SEM-EDS) ${ }^{11}$, spektroskopię w podczerwieni z transformatą Fouriera (FTIR) ${ }^{12}$, analizę przekrojów poprzecznych pobranych próbek przy użyciu mikroskopii standardowej VIS

6 Krystyna Czerni, Nietoperz w świątyni. Biografia Jerzego Nowosielskiego (Kraków: Znak, 2011), 80-83.

7 Czerni, Nietoperz, 298.

8 Czerni, Nowosielski, 29.

9 Fotografie w świetle VIS, w promieniowaniu UV oraz IR wykonał mgr Adam Cupa (Zakład Technologii i Technik Malarskich, Wydział Sztuk Pięknych, UMK).

10 Badanie przeprowadził mgr A. Cupa.

11 Badanie przeprowadziła dr Grażyna Szczepańska (Pracownia Analiz Instrumentalnych, Wydział Chemii, UMK).

12 Badanie spoiwa metodą spektroskopii w podczerwieni z transformatą Fouriera (FTIR) wykonała dr Teresa Kurkiewicz (Zakład Technologii i Technik Malarskich, Wydział Sztuk Pięknych, UMK). 
i mikroskopii fluorescencyjnej UV ${ }^{13}$. Identyfikację pigmentów przeprowadzono na podstawie analizy fotografii w technice „fałszywych kolorów” przekrojów poprzecznych pobranych próbek ${ }^{14}$ oraz badań mikrochemicznych.

Polichromie ścienne w Górowie Iławeckim zostały wykonane na dwóch podłożach: w prezbiterium i na ścianie zachodniej - bezpośrednio na ceglanym murze, a pod oknami w nawie, na parapecie chóru muzycznego oraz w przedsionku - na warstwie tynku, prawdopodobnie wapienno-piaskowego, pokrytego wapienną pobiałą. W obrazach Jerzego Nowosielskiego podłoże odgrywa istotną rolę, często na równych prawach współistniejąc z warstwą malarską i razem z nią tworząc ostateczny efekt optyczny. W taki właśnie sposób zostało wykorzystane w górowskiej cerkwi. Interesujące są zwłaszcza polichromie na ceglanym murze (fot. 4 i 5): ponieważ zostały wykonane bez żadnego podmalowania, ich kolorystyka jest wypadkową użytych barw oraz koloru cegieł i łączących je jasnych spoin, które, delikatnie prześwitując przez warstwę malarską, tworzą subtelny kraciasty wzór, widoczny głównie w świetle bocznym delikatny relief ceglanego wątku, nadający malowidłom wrażenie trójwymiarowości. Warto podkreślić, że cechy podłoża, takie jak nierówność lub chropowatość tynków, wyraźne uskoki cegieł i ich wykruszenia, nie przeszkadzały artyście - przeciwnie, potrafił je wykorzystać do uzyskania ciekawych efektów plastycznych. Widać to wyraźnie na przedstawieniu św. Piotra w prezbiterium: współdziałanie nierówności podłoża i lapidarnie nałożonej warstwy malarskiej sprawia, że miejscami wizerunek zatraca cechy figuracji, wkraczając w wymiar czysto abstrakcyjny (fot. 6). Ciekawy efekt związany z fakturą podłoża, a powstały w wyniku zabiegu przecierania, tworzą pozostałości farby w nierównych porach tynku. Z bliska wyglądają one jak drobno nałożone barwne plamki, oglądane z większej odległości zlewają się i tworzą iluzję delikatnie mżącej płaszczyzny.

13 Badanie przeprowadziła dr Magdalena Iwanicka (Zakład Konserwacji Malarstwa i Rzeźby Polichromowanej, Wydział Sztuk Pięknych, UMK). Interpretacji fotografii dokonała dr M. Iwanicka wspólnie z autorką artykułu.

14 Fotografie mikroskopowe przekrojów poprzecznych próbek w technice „fałszywych kolorów" wykonała Magdalena Kapka. Zdjęcia te oraz zdjęcia rejestrujące całe malowidła w technice „fałszywych kolorów” zostały zinterpretowane przez autorkę artykułu wspólnie z dr. hab. Jarosław Rogóżem, prof. UMK oraz mgr. A. Cupą. W trakcie analizy korzystano również z opracowań: Jarosław Rogóż, Zastosowanie technik nieniszczących w badaniach konserwatorskich malowideł ściennych (Toruń: Wydawnictwo Naukowe UMK, 2009); Aleksandra Wysokińska, „Utworzenie wzorcowej bazy obrazów cyfrowych pigmentów i barwników dla potrzeb analitycznych fluorescencji wzbudzanej ultrafioletem oraz techniki kolorowej podczerwieni” (praca magisterska, Uniwersytet Mikołaja Kopernika w Toruniu, 2016). 
Analiza wizualna malowideł oraz fotografii wykonanych w podczerwieni wykazała, że w niektórych partiach, zwłaszcza na krawędziach nimbów i szat, spod transparentnie nałożonej farby prześwituje delikatny rysunek w kolorze ciepłej szarości lub brązu. Został wykonany narzędziem dającym cienką linię, być może ołówkiem, kredką lub cienkim pędzelkiem rozwodnioną farbą. Taki wstępny szkic pomagał zapewne artyście uporządkować poszczególne elementy kompozycji i precyzyjnie namalować niemal idealne okręgi nimbów oraz kontury sylwetek świętych. Nie stwierdzono wyraźnych autorskich zmian kompozycyjnych, z wyjątkiem nieznacznego podwyższenia łuku nimbu Chrystusa w prezbiterium, o czym świadczy prześwitujący spod warstwy czerwieni wcześniejszy rysunek.

W pierwszej kolejności, zgodnie z regułami, jakie podaje między innymi rosyjski prawosławny teolog i teoretyk malarstwa ikonowego ojciec Paweł Florenski (1882-1937) ${ }^{15}$, jeszcze przed wykonaniem karnacji Nowosielski namalował tła, szaty, nimby oraz inne „nieosobowe” części przedstawienia ${ }^{16}$. Postępował zatem podobnie jak przy klasycznej ikonie, z tym jednak wyjątkiem, że w ikonopisaniu pierwszą czynnością po przygotowaniu podłoża często było nakładanie złota, które miało symbolizować nadprzyrodzone światło ${ }^{17}$. Nowosielski jednak twierdził, że „całe malarstwo tworzy się za pomocą kolorów”18 i celowo złota nie używał. Według o. Pawła Florenskiego farba jest zbyt płaska i brudna, aby wydobyć świetlaną głębię ${ }^{19}$. Tymczasem Nowosielski, posługujący się właśnie farbami, kolorami, potrafił dokonać ich niemal alchemicznej transformacji w malarskie światło. W miejsce ikono-

15 Piotr Przesmycki, „Świadek czystego światła”, $W$ drodze 1, nr 341 (2002), Dostęp 20 listopada 2017, https://www.wdrodze.pl/miesiecznik/index.php?mod=archiwumtekst\&id=13650\#. WhwOJEribIU.

16 Według o. P. Florenskiego, w języku malarzy ikon części osobowe to oblicze, ręce i nogi; wszystko inne - czyli tułów, odzież, szczegóły architektoniczne, elementy pejzażu - jest uznawane za nieosobowe. Paweł Florenski, Ikonostas i inne szkice, tłum. Zbigniew Podgórzec (Białystok: Bractwo Młodzieży Prawosławnej w Polsce, 1997), 187.

17 Zdaniem o. P. Florenskiego całą ontologię malarstwa ikonowego wyraża światło, dlatego „ikonę maluje się na świetle”. Zgodnie z tradycją ikonopisania do oznaczenia światła należy użyć złota, a więc objawia się ono nie jako kolor, lecz światło, blask. Florenski, Ikonostas, 188. Należy dodać, że kosztowne złoto często zastępowano farbą o barwie najbardziej do niego zbliżonej - żółtej, zielonej, czerwonej. Można to zauważyć np. w ikonach z północnej Rusi i Nowogrodu. Irena Jazykowa, Świat ikony, tłum. Henryk Paprocki (Warszawa: Wydawnictwo Księży Marianów, 1998), 33.

18 Jerzy Nowosielski, „Religia jest rzeczą bardzo niebezpieczną”, w Jerzy Nowosielski, Sztuka po końcu świata. Rozmowy, wybór i układ Krystyna Czerni (Kraków: Znak, 2012), 372.

19 Florenski, Ikonostas, 180. 
wych złotych teł artysta w Górowie Iławeckim użył bieli, w ikonie semantycznie najbardziej odpowiadającej złotu. Biel jako jednocześnie i kolor, i światło, symbolizowała czystość i wspólnotę z boskim światem ${ }^{20}$. Być może zatem malarz, zwykle unikający wszelkiej symboliki, tym znaczeniem bieli się właśnie kierował wykonując tła ikon w górowskiej cerkwi. Należy jednak wyjaśnić, że tła polichromii w nawie prawdopodobnie jeszcze przed połową lat dziewięćdziesiątych zostały jednolicie przemalowane białą farbą. Daje się to zauważyć zarówno dzięki fluorescencji wzbudzonej promieniowaniem UV, jak i w świetle widzialnym, zwłaszcza w partiach inskrypcji, gdzie nową warstwę malarską nałożono niedbale, miejscami nachodząc na litery i powodując ich zniekształcenie. Przed przemalowaniem tła pod oknami mogły więc być takie jak tła ikon na parapecie chóru - również białe, ale wykonane w stylu artysty, metodą tepowania i przecierek.

Ten charakterystyczny dla krakowskiego malarza sposób opracowywania większych płaszczyzn jest widoczny zarówno w partii tła parapetu chóru muzycznego, jak i na malowidłach wykonanych na pokrytym pobiałą tynku, w partiach nimbów i szat. Artysta w tych miejscach nakładał farbę w sposób transparentny lub kryjący, jednorodnie bądź nierównomiernie, różnicując kolor pod względem nasycenia i waloru. Stosował przy tym często wspomnianą metodę tzw. tepowania, lawowania i przecierał naniesioną farbę (fot. 7), a czasem dodatkowo jeszcze rozbijał te obszary drobniejszymi, nieregularnie nałożonymi plamami o różnej wielkości. Dzięki tym zabiegom uzyskiwał wrażenie wibracji koloru i rozedrgania płaszczyzny, spotęgowane przedzierającym się jaśniejszym kolorem podłoża. Tak wykonane nimby do złudzenia przypominają migoczące, pokryte patyną czasu złoto, a całe malowidła nabierają w ten sposób lekkości i świetlistości. Wyjątkowy sposób operowania przez malarza kolorem doceniła Bronisława Gumińska stwierdzając, że jego obrazy emanują blaskiem od środka, że „nawet czerń u Nowosielskiego świeci”21. W inny sposób artysta wykonywał malowidła, których podłożem był surowy mur ceglany - nakładając warstwę malarską również dość cienko, ale płasko i równomiernie. Widać to zwłaszcza w partiach nimbów Matki Bożej Orantki oraz Chrystusa w prezbiterium, stanowiących jednolitą, czerwoną plamę (fot. 4 i 5 ).

20 I. Jazykowa, Świat ikony, 33-34.

21 Bronisława Gumińska, wypowiedź w filmie Pantokrator. Rzecz o Jerzym Nowosielskim, scenariusz i realizacja Miłosz Kozioł, TP S.A. 2011. 
Opracowując światła na szatach świętych oraz innych partiach ikony, oprócz rozmywania i rozcierania barwnych powierzchni odsłaniającego jaśniejsze podłoże, artysta nakładał rozbieloną farbę użytą do namalowania spodniej warstwy, nanosił światła czystą bielą lub podkreślał je innym, intensywnym kolorem, np. jaskrawym jasnym błękitem lub czerwienią, jak na szatach Matki Bożej Orantki. Budując światła najczęściej zamaszyście, pośpiesznie nanosił farby o różnej konsystencji, operując pędzlem w różnych kierunkach, z pozostawieniem wyraźnych śladów szczecinowego włosia (fot. 8). Inny sposób modelowania świateł opierał się na nanoszeniu rozbielonych lub białych transparentnych pasm o różnych szerokościach i długościach, a następnie wmalowywaniu na nich wzdłuż formy jasnych, najczęściej białych, kryjących linii. Tak skonstruowane lśniące smugi oraz wszystkie podobnie wykonane linie w innych partiach kompozycji są oryginalną i rozpoznawalną cechą twórczości Nowosielskiego. Niczym malarski autograf oddają wyraźnie jego ekspresję oraz charakter, sposób i kierunek prowadzenia ręki. Niekiedy świetliste bliki na różnych elementach przedstawienia są tylko lekko zaznaczone, jakby zaledwie naszkicowane, ograniczone do kilku jasnych kresek, plamek. W podobny sposób powstawały linearne akcenty na szatach imitujące cienie w zagłębieniach fałd - najczęściej przez półkryjące namalowanie szerszych pasów, a następnie, już bardziej kryjąco, nałożenie wzdłuż nich cieńszych linii. Niekiedy artysta tworzył rysunek szat samymi liniami, bez podmalowania, różnicując ich długość, szerokość i stopień krycia, od grubych kryjących pasków po cienkie kreseczki.

Omawiając wykonanie „nieosobowych” części górowskich polichromii nie sposób pominąć ozdobnych elementów szat oraz atrybutów świętych, takich jak zwoje, księgi, krzyże, alabastrony ${ }^{22}$, makiety kościołów. Zostały one potraktowane niezwykle dekoracyjnie i linearnie. Rysunek poszczególnych form podkreślony został wyraźnym, zróżnicowanym pod względem przejrzystości konturem. Uwagę przykuwa między innymi precyzja wykonania liter na zwojach oraz detali na szatach i księgach, zwłaszcza imitujących okrągłe, złote zdobienia. Świetlistość tych elementów Nowosielski najczęściej wydobywał przez ich transparentne podmalowanie większymi jaśniejszymi plamkami, a następnie nałożenie na nie mniejszych akcentów wykonanych impastowo jaśniejszą, zazwyczaj żółtą farbą.

22 Anna Różycka-Bryzek, Bizantyńsko-ruskie malowidła w kaplicy zamku lubelskiego (Warszawa: PWN, 1983), 87 - autorka wskazuje na alabastron jako jeden z atrybutów św. Paraskewii. 
Należy podkreślić, że precyzja i pewność prowadzenia linii, kresek, konturów wyznaczających idealne niemal okręgi i regularne łuki jest znamienną cechą twórczości Jerzego Nowosielskiego i dobrze równoważy się z pośpiesznym i pozornie niedbałym modelunkiem w innych partiach kompozycji. Ksiądz Henryk Paprocki, który asystował artyście przy wykonywaniu malowideł ściennych w cerkwi prawosławnej na Woli w Warszawie, zaobserwował, że Nowosielski „jak już położył kreskę, nie trzeba było poprawiać. Nie używał żadnych linijek, niczego - na przykład nimby: po prostu brał pędzel i wychodziło piękne równe kółko. Za jednym pociągnięciem! Nie widziałem, żeby ktoś malował z równą precyzją”23.

Kolejnym etapem prac przy polichromiach było opracowanie karnacji. Ich wykonanie z jednej strony jest bardzo charakterystyczne dla malarstwa Jerzego Nowosielskiego, z drugiej zaś wyraźnie wskazuje, że artysta inspirował się warsztatem twórców tradycyjnych ikon ${ }^{24}$. Największe podobieństwo polega na stopniowym wyprowadzaniu świateł na ciemnobrązowym podmalowaniu, odpowiadającym sankirowi w klasycznej ikonie. Natomiast pewną osobliwością u Jerzego Nowosielskiego, występującą w niektórych karnacjach, jest słabo widoczne na pierwszy rzut oka podmalowanie ciemnego oblicza postaci jaśniejszą, rozwodnioną farbą, zazwyczaj brązową lub czerwoną. Można to zaobserwować między innymi na przedstawieniu św. Paraskewii, gdzie miejscami transparentnie nałożona ciemnobrązowa karnacyjna farba odsłania czerwone podłoże. W podobny sposób Nowosielski podmalowywał włosy oraz brody świętych. Jedynie na Mandylionie włosy zostały podmalowane dość kryjąco jaśniejszą niż w innych przedstawieniach czerwonobrązową farbą.

23 Henryk Paprocki, za: Czerni, Nietoperz, 311.

24 Według o. P. Florenskiego malowanie karnacji w tradycyjnej ikonie rozpoczynano od ciemnego podkładu, tzw. sankiru. Następnie przystępowano do „opisu konturów”, polegającego na zarysowaniu poszczególnych części anatomicznych karnacji. Później malarz dokonywał tzw. rozpłynniania farb na obliczu, a więc rozjaśniał czoło, nos i policzki rzadką farbą w kolorze ciała, mającą w swoim składzie ugier, inaczej ochrę, dlatego czynność tę nazywano również ochrowaniem. Warstwa ta była transparentna i zmiękczała ostrość nałożonego wcześniej opisu konturu. Tą samą farbą z dodatkiem czerwonych pigmentów - minii lub cynobru - malowano czerwień w partiach policzków. Aby uwydatnić nałożoną na sankir czerwień, nakładano w te miejsca nieco jaśniejszą ochrę, a kolejną warstwą ochry rozjaśniano miejsca najjaśniejsze, tzw. ożywiające. Na koniec rozrysowywano włosy, a w miejscach najwyższych świateł wykonywano tzw. bielidłem cieniutkie kreseczki i wąskie pasemka, czyli „dwiżki” i „otmietiny”. Florenski, Ikonostas, 191-192. Zob. też Jazykowa, Świat ikony, 36; Dionizjusz z Furny, Hermeneia, czyli objaśnienie sztuki malarskiej, tłum. Ireneusz Kania (Kraków, Wydawnictwo Uniwersytetu Jagiellońskiego, 2003), 26-27. 
Następnie malarz na partie czoła, policzków, nosa oraz dłonie i inne części ciała nakładał rozwodnioną farbę w kolorze czerwieni lub jaśniejszego, ciepłego brązu, którą zaznaczał także usta i bliki w partiach oczu. W ten sposób tworzył delikatny woal, który nawiązywał do czynności rozpłynniania w tradycyjnym malarstwie ikonowym. Dodatkowo tą samą farbą, tylko o gęstszej konsystencji, czasem z dodatkiem żółcieni lub bieli, podkreślał partie bardziej oświetlone. Niekiedy w tych miejscach używał innego koloru, na przykład na czerwone podlawowanie nakładał żółcień lub oranż, jak w karnacji św. Kosmy (fot. 9). Natomiast w miejscach najwyższych świateł wmalowywał bliki, często uzyskując efekt impastów. Niekiedy bliki namalowane są intensywną czerwienią i przybierają charakter bardziej linearny i graficzny, co można porównać do tradycyjnych kreseczek, czyli dwiżek lub pasemek, nazywanych inaczej otmietinami ${ }^{25}$. Nierzadko światła na karnacjach, podobnie jak na innych fragmentach kompozycji, namalowane zostały oszczędnie, kilkoma pojedynczymi pociągnięciami pędzla i wyglądają jakby celowo były tylko zasygnalizowane - na przykład w partii oczu są czasem ograniczone do pojedynczych plamek (fot. 9 i 10).

Charakterystyczny dla Jerzego Nowosielskiego modelunek warstwy malarskiej, polegający na stopniowym, warstwowym wyprowadzaniu świateł na ciemnym podmalowaniu, zaobserwować można w partiach włosów i brody niektórych świętych, na przykład św. Symeona (fot. 10). Na ciemnobrązowe podmalowanie malarz transparentnie nałożył lekko rozrzedzoną farbę w kolorze błękitu, następnie pośpiesznymi pociągnięciami pędzla, nieco bardziej laserunkowo, modelował te partie jasną szarością. Na koniec kryjąco, miejscami impastowo, wprowadził świetliste akcenty czystą bielą, z pozostawieniem wyraźnych śladów włosia pędzla, zdradzających kierunek nanoszenia farby. Modelunek partii włosów i brody był czasem bardziej precyzyjny, taki jak na przedstawieniu św. Teodozjusza Pieczerskiego, gdzie białe, naśladujące faliste pukle włosów linearne formy zostały namalowane w sposób bardziej regularny i uporządkowany. Podobnie wymodelowane zostały pasma włosów Chrystusa w prezbiterium. Artysta jednak celowo zmiękczał te formy, różnicując stopień krycia nakładanej w te miejsca farby.

Prawdopodobnie już na koniec Nowosielski na twarzach, dłoniach oraz włosach i brodach dodatkowo pogłębiał cienie przez wmalowanie ciemniej-

25 Florenski, Ikonostas, 192. 
szych, najczęściej linearnych akcentów, widocznych zwłaszcza w partiach oczu i brwi.

Czynnością wieńczącą prace nad górowskimi polichromiami było wykonanie inskrypcji, podobnie jak w klasycznej ikonie. Na Mandylionie oraz przedstawieniach św. Piotra i Matki Bożej Orantki napisy sporządzono jasnobłękitną farbą, natomiast na pozostałych malowidłach różnymi odcieniami czerwieni i ugru. Wszystkie inskrypcje zostały naniesione na wypełnione ciemnym tłem prostokątne i kwadratowe pola, które zachowały się tylko w prezbiterium oraz na ścianie zachodniej - reszta została zamalowana białą farbą użytą do „odświeżenia” teł polichromii w nawie. Litery cyrylicy, podobnie jak na zwojach, zostały namalowane w sposób niezwykle dekoracyjny i precyzyjny. Wykonanie napisów rozrzedzoną farbą, lekko i laserunkowo, złagodziło geometryczne formy liter.

Malowidła Jerzego Nowosielskiego powstały w technice akrylowej, od końca lat siedemdziesiątych dominującej w jego twórczości monumentalnej. O zamiłowaniu do niej artysta mówił między innymi w rozmowie ze Zbigniewem Podgórcem; uzasadniał, że najbardziej zbliża się do tempery, a więc klasycznej techniki ikony, i wyjaśniał: „Akrylem czy temperą mogę obraz ciągnąć bardzo długo. I takie długie prowadzenie malowidła daje, oczywiście, swoiste efekty estetyczne, które w jakiś sposób pogłębiają działanie malarskie. To działanie nosi na sobie ślad wielowarstwowości, ślad nawarstwiania się różnych koncepcji, które dojrzewają w trakcie powstawania obrazu. Są to rzeczy długodystansowe, wielowarstwowe i zapewne mogące dłuższy czas działać na widza”26.

Badania instrumentalne potwierdziły obecność spoiwa akrylowego w warstwie malarskiej, jednak niełatwe okazało się ustalenie, w jakiej formie zostało ono użyte. Przydatne w rozwiązaniu tej kwestii były informacje uzyskane od współpracowników i asystentów Jerzego Nowosielskiego ${ }^{27}$. Na ich podstawie można wnioskować, że malarz mógł w tym okresie posługiwać

26 Jerzy Nowosielski, Zbigniew Podgórzec, Rozmowy z Jerzym Nowosielskim. Wokół Ikony - Mój Chrystus - Mój Judasz (Kraków: Znak, 2014), 222-223.

27 Nie udało się uzyskać informacji od p. Haliny Onichimiuk-Piękny, która współpracowała z J. Nowosielskim w Górowie Iławeckim. Cenne informacje przekazali: p. Paweł Różewicz, artysta grafik, który pomagał J. Nowosielskiemu w pracy nad polichromiami w Lourdes w 1985 r. oraz w Warszawie-Wesołej w II połowie lat 70.; p. Paweł Sadlej, konserwator zabytków, który również asystował przy malowaniu wnętrza kościoła w Warszawie-Wesołej, a pod koniec lat 80. przy dekorowaniu wnętrza Domu Rekolekcyjnego; p. Maria Trzupek, która wyspecjalizowała się w konserwacji obrazów sztalugowych Nowosielskiego. 
się gotowymi farbami, np. produkcji Rowneya, które ze względu na wysoką jakość oraz bardziej zwartą, wręcz grudkowatą konsystencję przedkładał nad inne, np. produkcji Talensa. Z przeprowadzonych wywiadów wynika, że mógł również używać pigmentów i mieszać je ze spoiwem, tak jak podczas wykonywania polichromii w kościele i Domu Rekolekcyjnym w Warszawie-Wesołej, a także we Francji, gdzie wykorzystał spoiwa i pigmenty produkcji Lascaux oraz Lefranc-Bourgeau. Jest również prawdopodobne, że Nowosielski mieszał gotowe farby z pigmentami, spoiwem akrylowym i wodą, a być może dodawał też innych, polimerowych mediów, na przykład opóźniających schnięcie mediów akrylowych ${ }^{28}$. Nie zostało to jednak dotąd potwierdzone badaniami.

Analiza składu pierwiastkowego próbek pobranych z niektórych białych obszarów kompozycji, między innymi szaty św. Teodozjusza Pieczerskiego, wykluczyła obecność bieli tytanowej oraz cynkowej. Spora ilość znajdującego się w nich wapnia może wskazywać na sporządzenie przez Nowosielskiego farby z dodatkiem kredy lub pozostawienie bieli podłoża, a więc znajdującej się pod spodem pobiały wapiennej ${ }^{29}$. Obecność bieli tytanowej wykazano natomiast w innych partiach kolorystycznych, na przykład w białym podmalowaniu żółtych kropek na szacie św. Jozafata. Obok tytanu zidentyfikowano tam również wapń ${ }^{30}$ oraz cynk, niewykluczony jest zatem dodatek kredy i bieli cynkowej. Należy brać pod uwagę zarówno samodzielne mieszanie przez artystę różnych białych pigmentów, jak i występowanie tych pierwiastków w gotowych farbach. Obecność baru, wapnia i siarki w próbkach pobranych

28 Wykaz niektórych polimerowych materiałów malarskich, m.in. produkcji Rowneya i Talensa, zob. Jerzy Werner, Podstawy technologii malarstwa i techniki (Warszawa, Kraków: PWN, 1981), 91-95.

${ }^{29}$ Miejsca te wykazują inną fluorescencję wzbudzoną promieniowaniem UV niż jasne fragmenty malowane przy użyciu spoiwa akrylowego.

30 Artysta w tym okresie mógł używać pigmentów firmy G. Rowney and Co. Ltd., w tym bieli nr 011; B. Kotarba, bliski współpracownik J. Nowosielskiego, potwierdził, że posługiwał się on tymi pigmentami już w latach 70. Magdalena Pieczonko, „Konserwacja i restauracja 2 malowideł Jerzego Nowosielskiego: obrazu sztalugowego Akt olej płótno; malowidła ściennego Matka Boża Ornatu w otoczeniu świętych na pomniku nagrobnym ks. Jerzego Klingera na Cmentarzu Prawosławnym na Woli w Warszawie” (dokumentacja konserwatorska, ASP w Warszawie 1999, 12 (Biblioteka Wydziału Konserwacji i Restauracji Dzieł Sztuki ASP w Warszawie). Analiza składu pierwiastkowego pigmentu (konkretnie: z puszki Rowneya pochodzącej z lat 80.) wykazała obecność zarówno wapnia, jak i tytanu, a więc pierwiastków również występujących w próbkach pobranych z białych partii. Nowosielski mógł wtedy używać również pigmentów Lefranc-Bourgeois (zob. przyp. 26), ale nie było możliwości przebadania pigmentów tej firmy z tego okresu. 
z innych partii kolorystycznych może wskazywać na zastosowanie również bieli barytowej. Intensywność tak charakterystycznych dla Nowosielskiego czerwieni i żółcieni sugerowała użycie przezeń cynobru lub pigmentów kadmowych, jednak w żadnej z badanych próbek z tych partii kolorystycznych nie wykryto ani kadmu, ani rtęci. Wyniki badań nieinwazyjnych oraz analizy materiału badawczego potwierdzają zastosowanie przez Nowosielskiego syntetycznych żółcieni oraz czerwieni organicznych ze wskazaniem między innymi na kraplak alizarynowy. Malarz modyfikował odcienie czerwieni i oranży przez odpowiedni dodatek żółcieni oraz prawdopodobnie bieli ${ }^{31}$. Do pigmentów z tej gamy kolorystycznej należą również zidentyfikowane w badaniach czerwone i żółte pigmenty żelazowe (m.in. ugier, siena). Spośród innych żelazowych pigmentów Nowosielski wykorzystał w górowskich malowidłach brązy - w tym umbrę paloną i naturalną. Znaczącą rolę w kolorystyce tych polichromii odgrywają błękity; badania wykazały, że artysta stosował ultramarynę syntetyczną, błękit manganowy oraz błękit ftalocyjanowy (fot. 11, 12 i wykres 1). Analizy próbek pobranych z partii zieleni wykluczyły obecność chromu i miedzi, wskazując na użycie zieleni organicznej, a także mieszaniny błękitu manganowego i żółcieni organicznej. Czarne cząsteczki pigmentów, obecne między innymi w próbkach z partii ciemnego błękitu oraz karnacji, zidentyfikowano jako czerń kostną.

Charakterystyczną cechą niemal wszystkich pobranych z różnych partii kolorystycznych próbek jest występowanie w nich sporej ilości baru i siarki. Może to sugerować albo użycie przez artystę bieli barytowej w sporządzonych samodzielnie barwnych mieszaninach ${ }^{32}$, albo - co wydaje się bardziej prawdopodobne - obecność siarczanu baru jako wypełniacza w pigmentach i gotowych farbach akrylowych ${ }^{33}$.

31 Należy wziąć pod uwagę dodatek żółcieni i bieli w gotowych farbach. W próbce pobranej z czerwieni szaty św. Paraskewii zidentyfikowano cynk, co może wskazywać na obecność bieli cynkowej zarówno w gotowej farbie, jak i w mieszaninie sporządzonej przez malarza.

32 Syntetyczny siarczan baru $\left(\mathrm{BaSO}_{4}\right)$ jest stosowany jako wypełniacz zapraw, domieszka do innych pigmentów, nośnik barwników organicznych w produkcji lak. Jest odporny na alkalia i z tego względu może być wykorzystywany w technikach wapiennych. Piotr Rudniewski, Pigmenty i ich identyfikacja (Warszawa: ASP w Warszawie, 1994), 42; Max Doerner, Materiały malarskie i ich zastosowanie, tłum. Franciszek Aleksandrowicz (Warszawa: Arkady, 1975), 50; Werner, Podstawy technologii, 18; Małgorzata Zubielewicz i Elżbieta Kamińska-Tarnawska, Pigmenty $i$ wypełniacze. Wpływ upakowania fazy stałej na właściwości wyrobów lakierowych (Toruń: Instytut Inżynierii Materiałów Polimerowych i Barwników, 2013), 52-53.

33 Ze względu na prawdopodobieństwo użycia w Górowie Iławeckim farb akrylowych Cryla marki Rowney przeprowadzono analizę składu pierwiastkowego tych farb, których odcie- 
Przeprowadzone badania technologiczno-techniczne górowskich polichromii ściennych dają podstawy do wskazania cech typowych dla twórczości Jerzego Nowosielskiego, odzwierciedlających jego niepowtarzalny styl i ekspresję. Analiza materiałów malarskich i sposobu ich użycia ujawniła skłonności artysty do poszukiwania nowych, twórczych rozwiązań, dzięki którym uzyskiwał szeroki wachlarz efektów plastycznych. Na owe efekty z pewnością miał wpływ wybór podłoża, którego kolor i fakturę, a nawet niedoskonałości, Nowosielski potrafił plastycznie zsynchronizować z nakładanymi warstwami barwnymi. Duże znaczenie miało zastosowanie nowoczesnych materiałów malarskich, w tym techniki akrylowej, pozwalającej pracować zarówno alla prima, jak i wielowarstwowo. Artysta w pełni korzystał z możliwości, jakie daje spoiwo akrylowe, tworząc między innymi przetarcia i przemycia w poszczególnych warstwach. Nakładał farbę o różnej konsystencji płasko i przestrzennie, za pomocą tepowania, lawowania, rozbijania płaszczyzn drobnymi plamami, i modelował transparentność tych warstw - od miękkich laserunków po fakturalne impasty, pozostawiając w nich często namacalne ślady swoich działań, takich jak wyraźne dukty pędzla. Nie czekając zbyt długo na wyschnięcie położonej farby, mógł pracować dość szybko. Analiza technologiczna nie dała jednoznacznej odpowiedzi, w jakiej formie Nowosielski stosował spoiwo akrylowe - czy w dyspersji wodnej, mieszając je z pigmentami, czy jako gotowe farby. Informacje współpracowników artysty wskazują, że mógł korzystać z obu form, a nawet je łączyć, co wydaje się dość prawdopodobne w świetle jego eksperymentatorskich skłonności. W wyniku badań fizykochemicznych zostały rozpoznane pigmenty użyte przez Nowosielskiego w poszczególnych partiach kolorystycznych, w tym tak charakterystyczne dla jego malarstwa żółcienie, czerwienie i błękity. Ich intensywność malarz uzyskał sięgając po syntetyczne żółte i czerwone pigmenty organiczne, a także błękit manganowy i ftalowy oraz sztuczną ultramarynę.

Na zakończenie należy podkreślić, że tak odważne, mające wrażeniowy charakter i nowatorskie podejście Jerzego Nowosielskiego do malarstwa poparte było dużą świadomością artystyczną, wiedzą i umiejętnością wyboru

nie odpowiadają cerkiewnym malowidłom, m.in. Vermilion Hue, Permanent Yellow, Primary Yellow, Crimson, Alizarin Crimson. We wszystkich badanych farbach stwierdzono obecność w stosunkowo największej ilości baru i siarki, co może potwierdzać dodatek siarczanu baru jako wypełniacza. Należy jednak wziąć pod uwagę, że badania przeprowadzono na współczesnych farbach, a ich skład od lat 80. mógł się zmienić. Analizę XRF farb przeprowadził mgr A. Cupa. 
i stosowania materiałów malarskich. Jak pisze Krystyna Czerni, Nowosielski opowiadając o mechanizmach tworzenia kładł nacisk na napięcie między intuicją a spekulacją ${ }^{34}$, a jako profesor krakowskiej ASP powtarzał studentom, że spontaniczność i intuicję należy koniecznie „przepuścić przez wiedzę"35. Potwierdzeniem tych słów mogą być jego polichromie ścienne w Górowie Iławeckim.

\section{Bibliografia}

Ciężka, Paula. „Artystyczna asymilacja. Przemiany historyczno-kulturowe w obecnej cerkwi w Górowie Iławeckim". W Światło Wschodu w przestrzeni gotyku, red. Katarzyna Pasławska-Iwanczewska, 245-264. Górowo Iławeckie: Parafia Greckokatolicka pw. Podwyższenia Krzyża Świętego, 2013.

Czerni, Krystyna. „Katalog projektów i realizacji sakralnych Jerzego Nowosielskiego”. W Krystyna Czerni. Nowosielski, 209-215. Kraków: Znak, 2006.

Czerni, Krystyna. Nietoperz w świątyni. Biografia Jerzego Nowosielskiego. Kraków: Znak, 2011.

Czerni, Krystyna. Nowosielski. Kraków: Znak, 2006.

Czerni, Krystyna. „Projekty i realizacje sakralne Jerzego Nowosielskiego dla cerkwi greckokatolickiej”. W Światło Wschodu w przestrzeni gotyku, red. Katarzyna Pasławska-Iwanczewska, 81-82. Górowo Iławeckie: Parafia Greckokatolicka pw. Podwyższenia Krzyża Świętego, 2013.

Czerni, Krystyna. „Ryzyko głośnego myślenia”. W Jerzy Nowosielski. Sztuka po końcu świata. Rozmowy. Wybór i układ Krystyna Czerni. 5-10. Kraków: Znak, 2012.

Dionizjusz z Furny. Hermeneia, czyli objaśnienie sztuki malarskiej. Tłumaczenie Ireneusz Kania. Kraków: Wydawnictwo Uniwersytetu Jagiellońskiego, 2003.

Doerner, Max. Materiały malarskie i ich zastosowanie. Tłumaczenie Franciszek Aleksandrowicz. Warszawa: Arkady, 1975.

Florenski, Paweł. Ikonostas i inne szkice. Tłumaczenie Zbigniew Podgórzec. Białystok: Bractwo Młodzieży Prawosławnej w Polsce, 1997.

Gumińska, Bronisława. Wypowiedź w filmie Pantokrator. Rzecz o Jerzym Nowosielskim. Scenariusz i realizacja Miłosz Kozioł. TP S.A., 2011.

Jazykowa, Irena. Świat ikony. Tłumaczenie Henryk Paprocki. Warszawa: Wydawnictwo Księży Marianów, 1998.

Nowosielski, Jerzy. „Religia jest rzeczą bardzo niebezpieczną”. W Jerzy Nowosielski. Sztuka po końcu świata. Rozmowy. Wybór i układ Krystyna Czerni, 371-385. Kraków: Znak, 2012.

34 K. Czerni, „Ryzyko głośnego myślenia”, w Nowosielski, Sztuka, 8.

35 Jerzy Nowosielski, za: K. Czerni, Ryzyko głośnego myślenia, w Nowosielski, Sztuka, 8. 
Nowosielski, Jerzy. Sztuka po końcu świata. Rozmowy. Wybór i układ Krystyna Czerni. Kraków: Znak, 2012.

Nowosielski, Jerzy, i Zbigniew Podgórzec. Rozmowy z Jerzym Nowosielskim. Wokół Ikony - Mój Chrystus - Mój Judasz. Kraków: Znak, 2014.

Pieczonko, Magdalena. „Konserwacja i restauracja 2 malowideł Jerzego Nowosielskiego: obrazu sztalugowego Akt olej płótno; malowidła ściennego Matka Boża Ornatu w otoczeniu świętych na pomniku nagrobnym ks. Jerzego Klingera na Cmentarzu Prawosławnym na Woli w Warszawie”. Dokumentacja konserwatorska, ASP w Warszawie 1999, mps w bibliotece Wydziału Konserwacji i Restauracji Dzieł Sztuki ASP w Warszawie

Piotrowska, Joanna. „Jerzy Nowosielski wobec tradycji bizantyńskiej”. W Światło Wschodu w przestrzeni gotyku, red. Katarzyna Pasławska-Iwanczewska, 121-130. Górowo Iławeckie: Parafia Greckokatolicka pw. Podwyższenia Krzyża Świętego, 2013.

Przesmycki, Piotr. „Świadek czystego światła”. W drodze 1, nr 341 (2002). Dostęp 20 listopada 2017, https://www.wdrodze.pl/miesiecznik/index.php?mod=archiwumtekst\&id=13650\#.WhwOJEribIU.

Rogóż, Jarosław. Zastosowanie technik nieniszczących w badaniach konserwatorskich malowideł ściennych. Toruń: Wydawnictwo Naukowe UMK, 2009.

Różycka-Bryzek, Anna. Bizantyńsko-ruskie malowidła w kaplicy zamku lubelskiego. Warszawa: PWN, 1983.

Rudniewski, Piotr. Pigmenty i ich identyfikacja. Warszawa: ASP w Warszawie, 1994.

Werner, Jerzy. Podstawy technologii malarstwa i techniki. Warszawa, Kraków: PWN, 1981. Wysokińska, Aleksandra. „Utworzenie wzorcowej bazy obrazów cyfrowych pigmentów i barwników dla potrzeb analitycznych fluorescencji wzbudzanej ultrafioletem oraz techniki kolorowej podczerwieni”. Praca magisterska, Uniwersytet Mikołaja Kopernika w Toruniu, 2016.

Zubielewicz, Małgorzata, i Elżbieta Kamińska-Tarnawska. Pigmenty i wypetniacze. Wpływ upakowania fazy stałej na właściwości wyrobów lakierowych. Toruń: Instytut Inżynierii Materiałów Polimerowych i Barwników, 2013. 


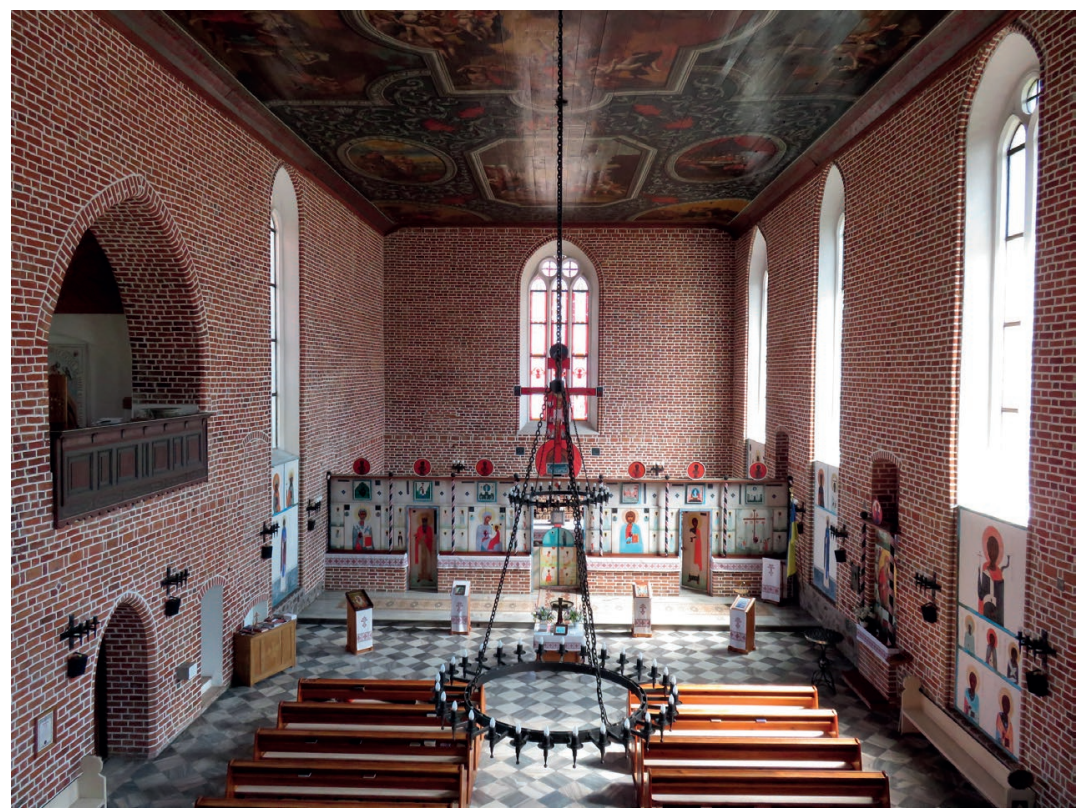

Fot. 1. Górowo Iławeckie, cerkiew pw. Podwyższenia Krzyża Świętego. Widok wnętrza cerkwi. Fot. Magdalena Kapka

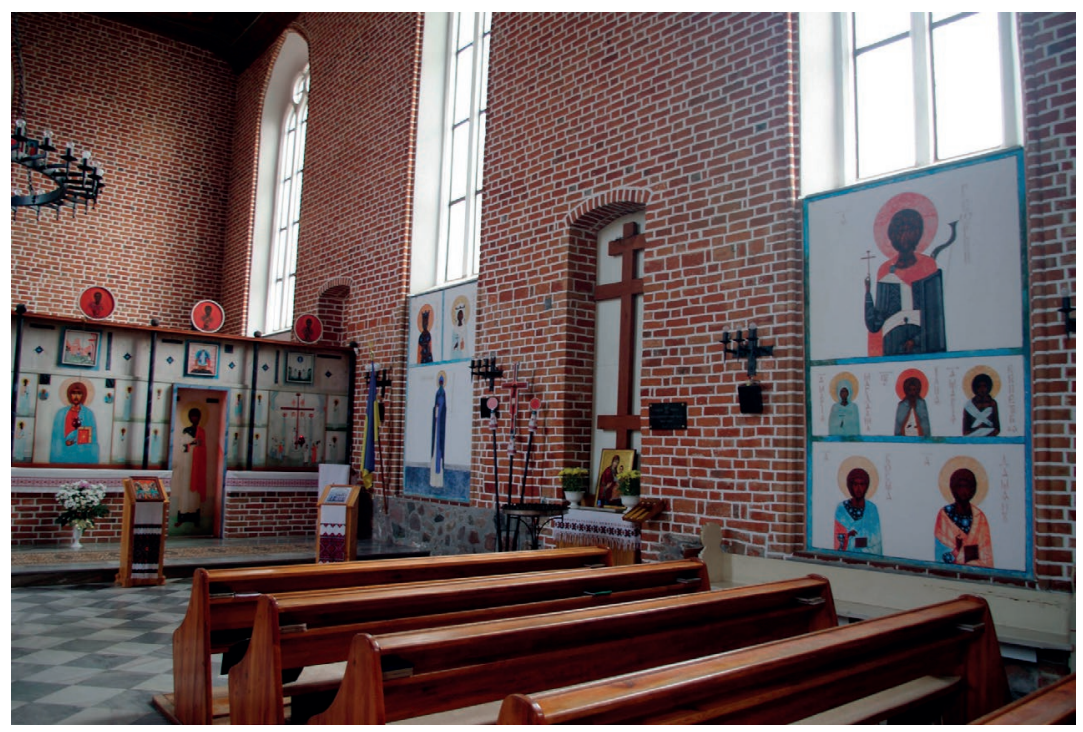

Fot. 2. Górowo Iławeckie, cerkiew pw. Podwyższenia Krzyża Świętego. Fragment ściany południowej z malowidłami Jerzego Nowosielskiego. Fot. Magdalena Kapka 


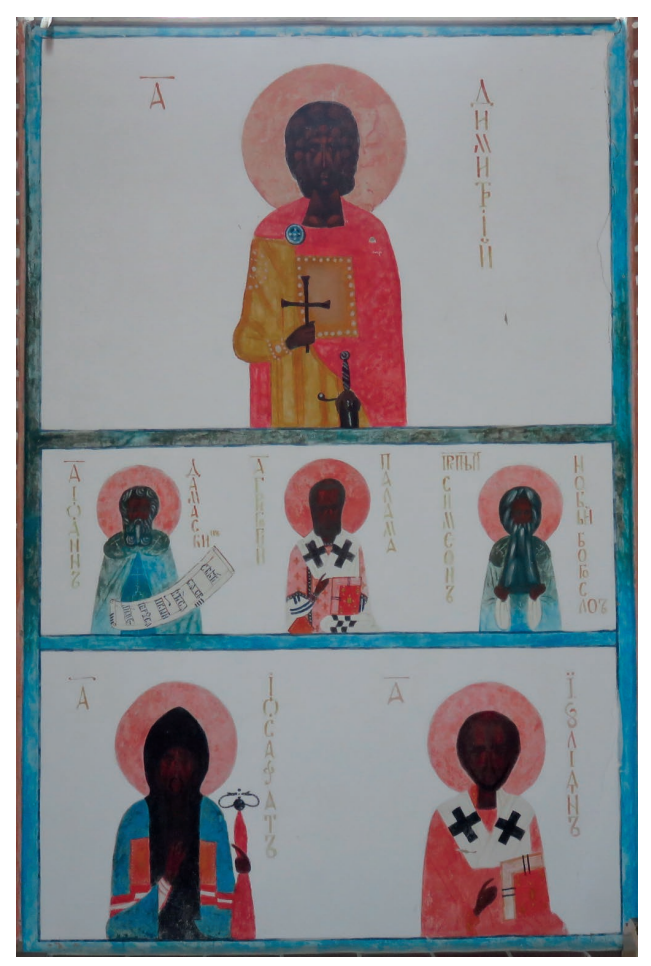

Fot. 3. Górowo Iławeckie, cerkiew pw. Podwyższenia Krzyża Świętego. Malowidła na ścianie południowej nawy głównej - święci: Dymitr, Jan Damasceński, Grzegorz Palamas, Symeon, Jozafat i Julian. Fot. Adam Cupa

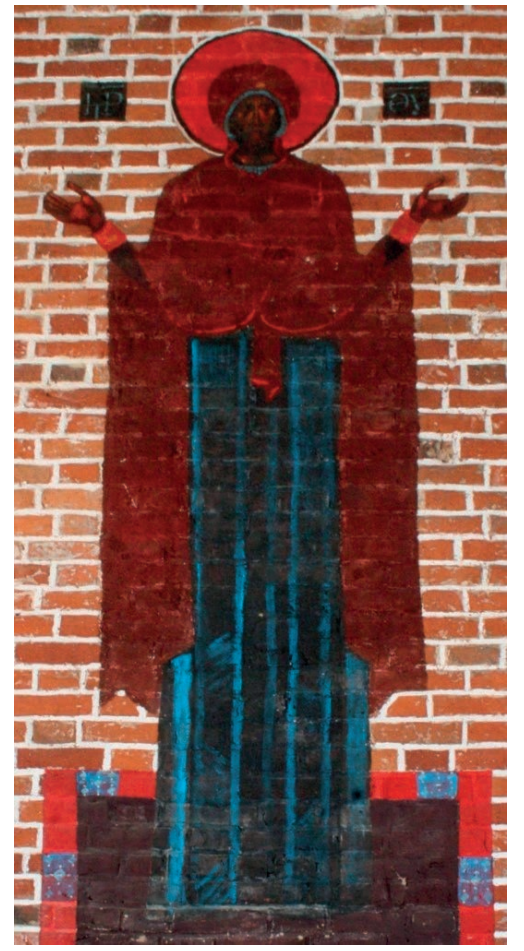

Fot. 4. Górowo Iławeckie, cerkiew pw. Podwyższenia Krzyża Świętego. Polichromia na ścianie zachodniej - Matka Boża Orantka. Fot. Magdalena Kapka 


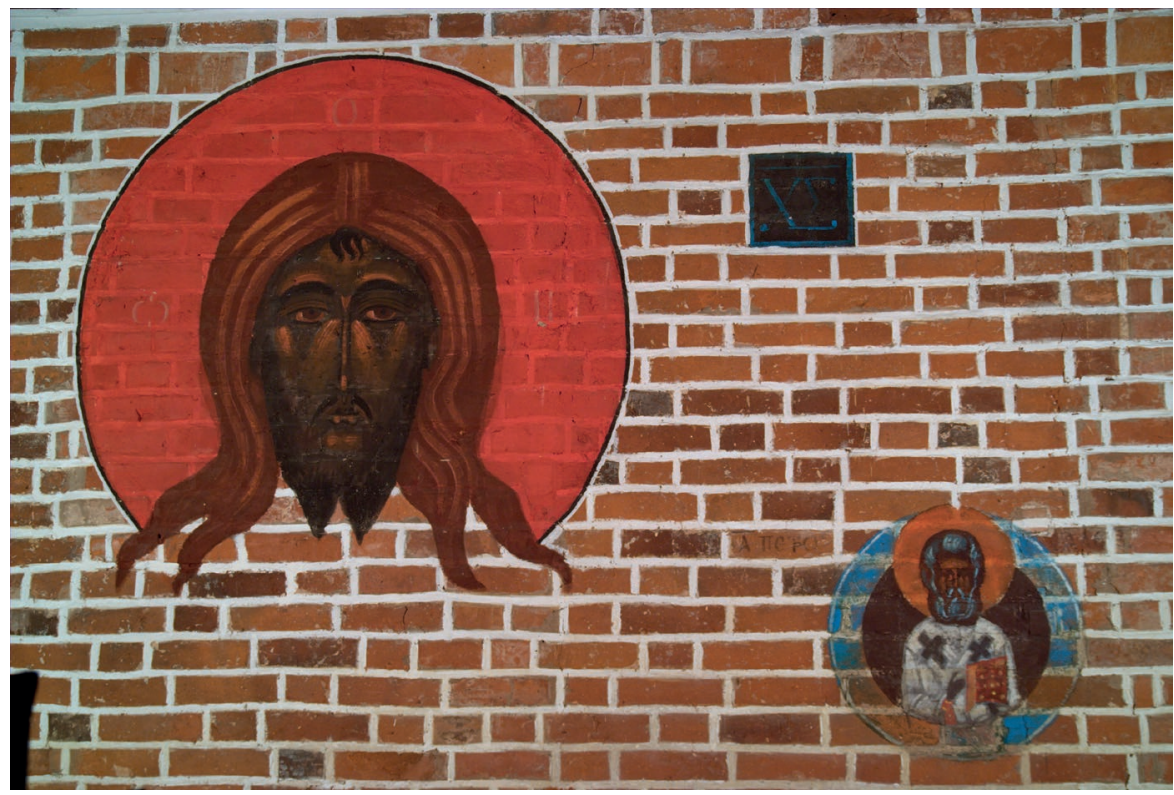

Fot. 5. Górowo Iławeckie, cerkiew pw. Podwyższenia Krzyża Świętego. Polichromie na ścianie wschodniej prezbiterium - Chrystus w typie Mandylionu i św. Piotr. Fot. Adam Cupa

Fot. 6. Górowo Iławeckie, cerkiew pw. Podwyższenia Krzyża Świętego. Ściana wschodnia - fragment wizerunku św. Piotra. Widoczny sposób malarskiego opracowania karnacji. Fot. Magdalena Kapka

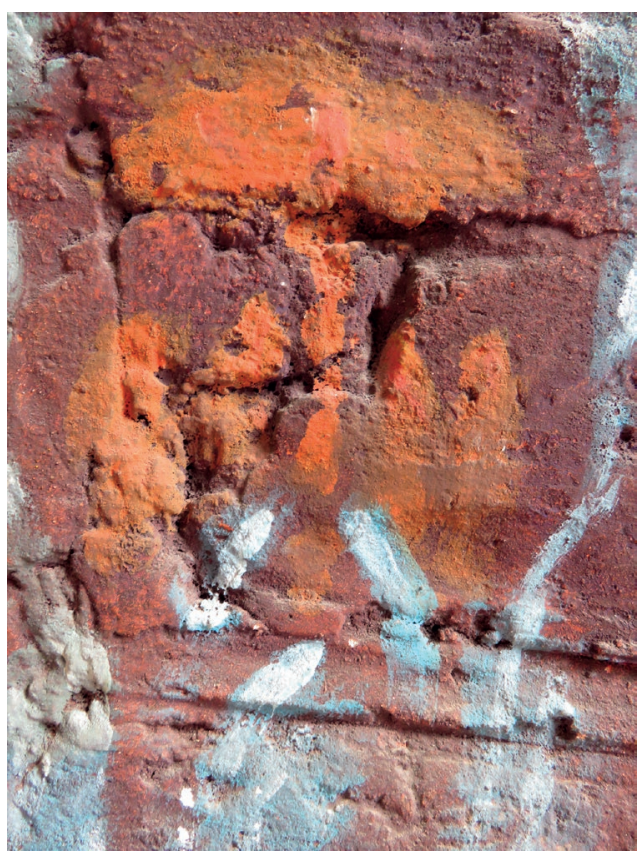




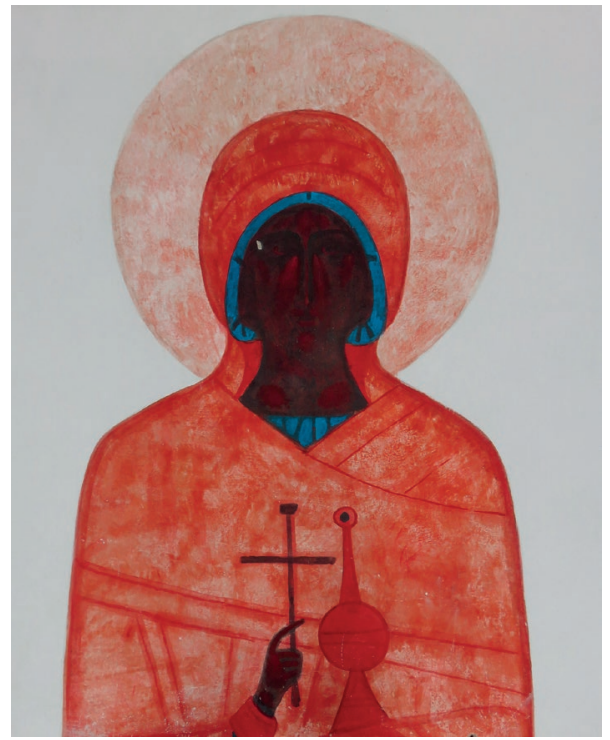

Fot. 7. Górowo Iławeckie, cerkiew pw. Podwyższenia Krzyża Świętego. Ściana północna nawy głównej - fragment przedstawienia św. Paraskewii. Fot. Magdalena Kapka

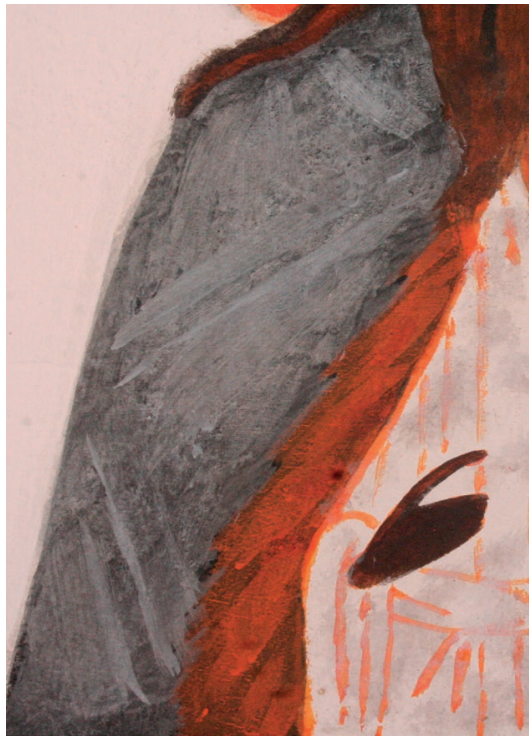

Fot. 8. Górowo Iławeckie, cerkiew pw. Podwyższenia Krzyża Świętego. Ściana południowa - fragment opracowania malarskiego szaty proroka Eliasza. Fot. Magdalena Kapka 


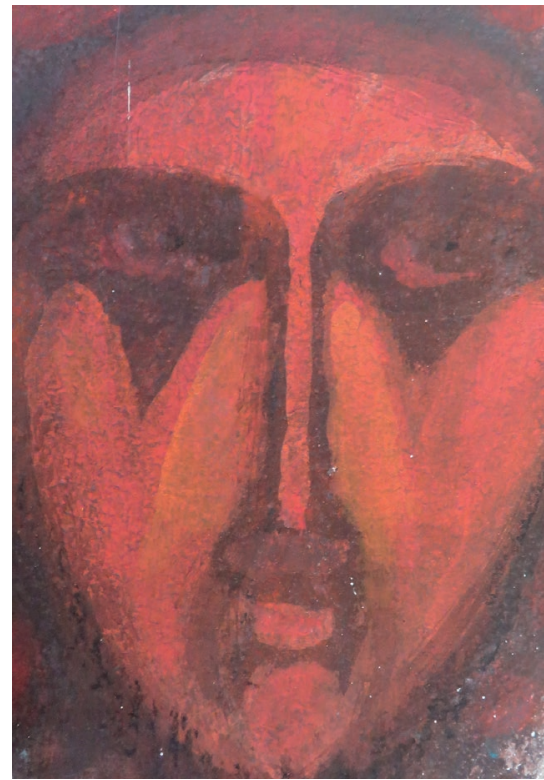

Fot. 9. Górowo Iławeckie, cerkiew pw. Podwyższenia Krzyża Świętego. Malowidło na Ściana południowa - wizerunek św. Kosmy (fragment karnacji). Fot. Magdalena Kapka

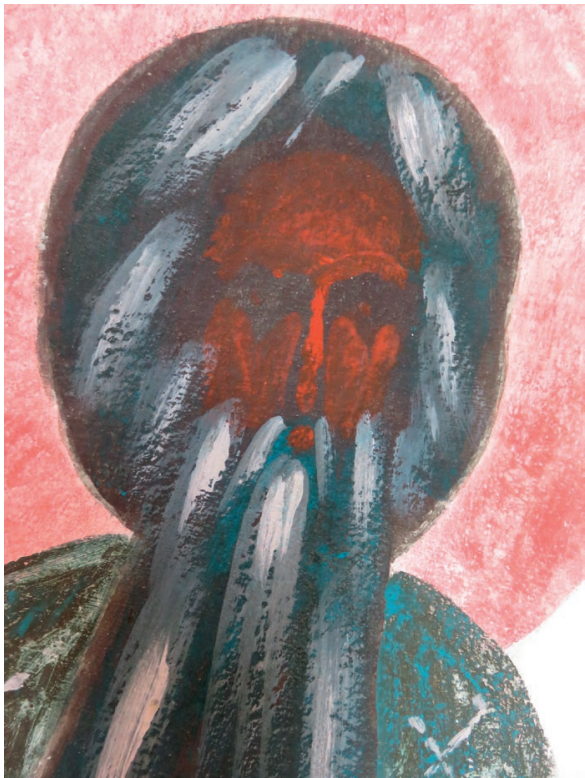

Fot. 10. Górowo Iławeckie, cerkiew pw. Podwyższenia Krzyża Świętego. Ściana południowa - fragment malowidła przedstawiający sposób malarskiego opracowania partii karnacji, włosów i brody św. Symeona. Fot. Magdalena Kapka 


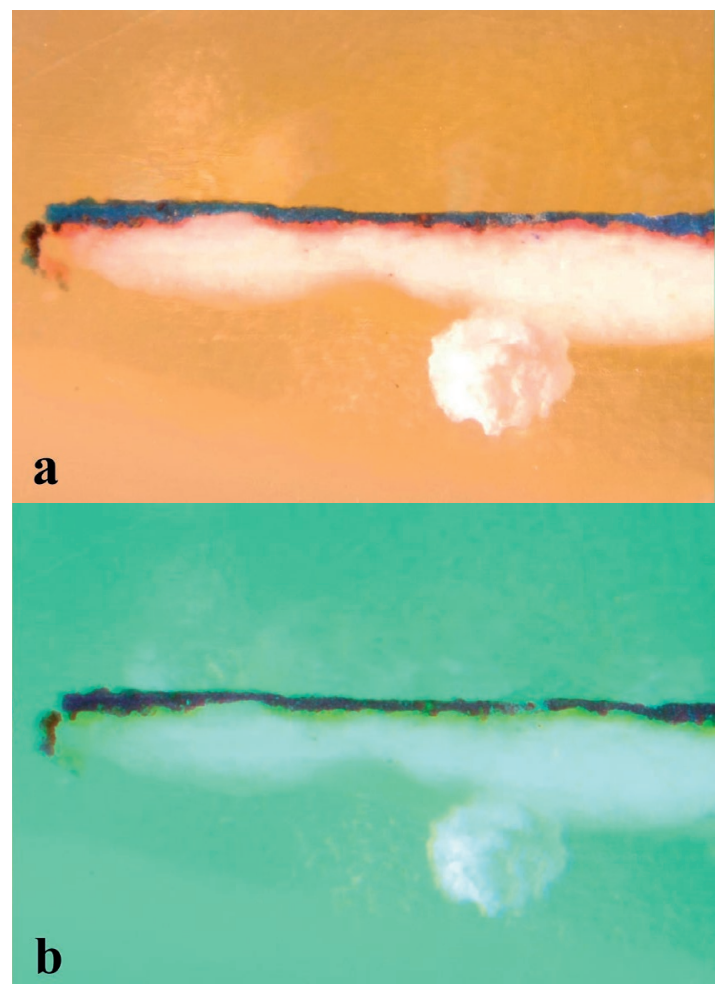

Fot. 11. Przekrój poprzeczny próbki pobranej z błękitnej lamówki maforionu św. Paraskewii. Fotografie wykonane świetle VIS (a) i w technice „fałszywych kolorów” (b). Warstwa błękitna zawiera błękit manganowy, natomiast czerwona - syntetyczną czerwień organiczną, prawdopodobnie z niewielkim dodatkiem bieli cynkowej. Fot. Magdalena Kapka 


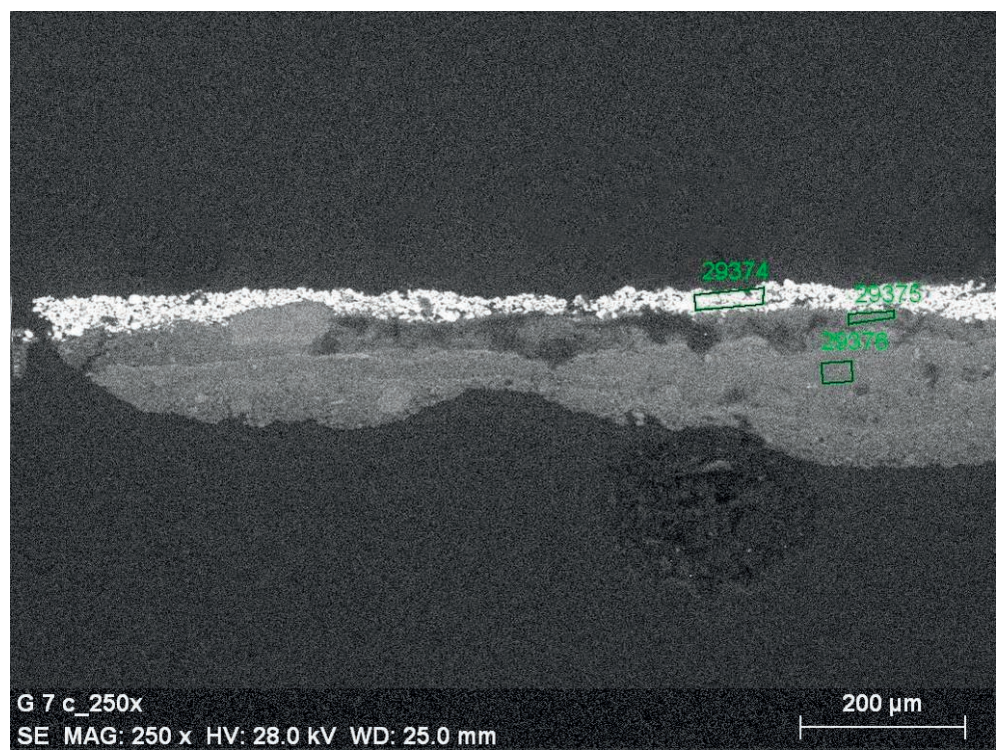

Fot. 12. Obraz skaningowy (SEM) w świetle elektronów odbitych (BEI) próbki błękitu z lamówki maforionu św. Paraskewii. Zielonymi ramkami oznaczono obszary analizy. Fot. Grażyna Szczepańska

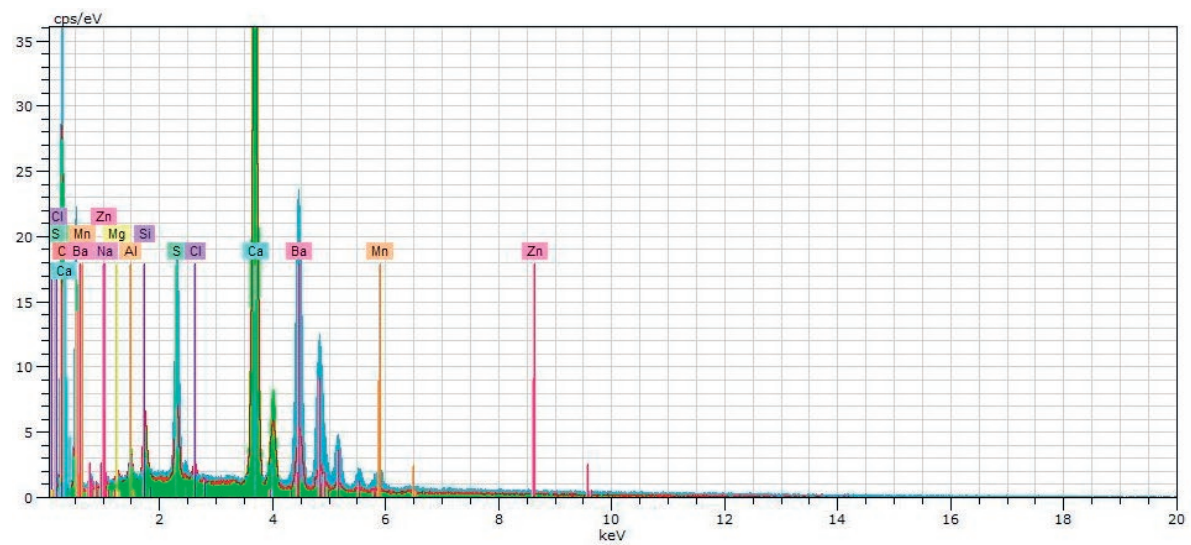

Wyk. 1. Wyniki energodyspersyjnej analizy rentgenowskiej (mikrosonda SEM-EDS) próbki błękitnej warstwy malarskiej pobranej z lamówki maforionu św. Paraskewii: obszar nr 29374 (zaznaczony na niebiesko) - O, Ba, C, S, Ca, Mn, Na, Al, Si; obszar nr 29375 (zaznaczony na czerwono) - O, C, Ca, Ba, S, Si, Al, Mg, Zn, Cl, Na; obszaru nr 29376 (zaznaczonego na zielono) - O, Ca, C, Si, Ba, Al, Mg, Na, S, Cl. Rys. wygenerowany w programie podczas analizy SEM-EDS przeprowadzonej przez Grażynę Szczepańską 
